\title{
Stomatal Index of a few common tree species in the Kishangarh Marble Slurry Dump-yard area, Ajmer (Rajasthan): A case study
}

\begin{abstract}
Lata Gahlot
Department of Botany, Samrat Prithviraj Chouhan Government College, Ajmer (Rajasthan), India

Vibha Khanna*

Department of Botany, Samrat Prithviraj Chouhan Government College, Ajmer (Rajasthan), India

*Corresponding author. E-mail: vibhaajmer@yahoo.co.in

Abstract

The size and number of the stomata present on the foliar epidermis of Tree species is directly influenced by the Suspended Particulate Matter. Marble dust is a very fine powder having approximately $40 \%$ particles below $75 \mu \mathrm{m}$ diameter of which approximately $30 \%$ are having a size less than $25 \mu \mathrm{m}$ present in the atmosphere. A comparative micromorphological study of stomatal index of the dominant tree speciesAlbizialebbeck, Azadirachta indica, Callistemon lanceolatus growing in the vicinity of Marble slurry dumpyard, Kishangarh (Ajmer) was done from the month of April 2014 to March 2015. The stomatal index of the lower epidermis of $A$. indica and $A$. lebbeck leaves from polluted sites was found to have greater value as compared to that with those of unpolluted site during the months of May to October while in case of the rough, leathery leaves of Callistemon lanceolatus, the stomatal index value in leaves from polluted site was less during these months. This may be attributed to the prevailing winds and weather conditions in the area of study which play a crucial role in the accumulated particulate matter on the phylloplane of the selected tree species viz.A. lebbeck, A. indica, C. lanceolatus
\end{abstract}

Keywords: Albizia lebbeck, Azadirachta indica,Callistemon lanceolatus, Marble-slurry and Stomatal index

\section{INTRODUCTION}

Rajasthan is known for mining of minerals and marbles. The State produces over $95 \%$ of the marble produced in India. Rajasthan State produces more than 65 types of mineral and rocks. The State is endowed with vast deposits of natural rocks known as- stones in local parlance and a few important ones amongst them are Granite, Marble, Sandstone, Limestone, Slate and Quartzite (MSME, 2017). A large number of mines and mining industrial process can produce particulate emission (Fennelly, 1975).

Rajasthan has around 4000 marble mines and about 1100 marble gang saws (processing units). Districts Ajmer (Makrana), Rajsamand, Udaipur, Chittorgarh, Banswara, Alwar, Sirohi, Jaipur etc are known for the mining of Marble and at the same time it has led to growth of many processing units engaged in cutting of marble in the form of Gang saw and cutters(Kushwah and Chaurasiya, 2015).

Dust particles form a major part of air pollutants arising due to industrial processes and pose serious threat to the ecosystem. (Shrivastava, 2017).

\section{Article Info}

DOI: 10.31018/jans.v11i1.1977 Received: January 9, 2019 Revised: February 24, 2019 Accepted: February 28, 2019

\section{How to Cite}

Gahlot, L. and Khanna, V. (2019). Stomatal Index of a few common tree cpecies in the Kishangarh Marble Slurry Dump-yard area, Ajmer (Rajasthan): A case study. Journal of Applied and Natural Science, 11 (1): 193-198 
taxes are paid thereby contributing to the regional revenue. The public revenue is further put for public expenditure as mentioned by the Rajasthan State Industrial Development and Investment Corporation Ltd. (Saxena et al., 2017).

Dust particles form a major part of air pollutants arising due to industrial processes andpose serious threat to the ecosystem. (Shrivastava, 2017). The environmental degradation of the land due to marble mining is much less than the environmental degradation caused by the waste from marble processing plants. The processing waste of marble cutting plants comes out in the form of 'Marble Slurry'. This marble slurry is being dumped by the processing plants at the nearest site available or in the notified areas marked for dumping. When this slurry dries up, it leads to serious environmental pollution (Kushwah, 2014). Pollutants have deleterious effect on stomata movements, foliar geometry, photosynthesis, membrane permeability and transportation of nutrients leading to stunted growth, poor yield and premature senescence in highly susceptible plants (Soni et al., 2017). This suspended particulate matter not only affects the plant physiology and anatomy, thereby retarding the growth but also causes micromorphological alterations in the plant. Foliar surface of plants is the main receptor of dust as it is continuously exposed to the surrounding atmosphere (Rai and Panda, 2014).

The effect of dust pollution on plant body damage plant tissue which may reduce rate of photosynthesis. Deposition of dust particles exert stress on plant resulting in reduction of productivity of the plants (Supeand Gawande, 2015).The Air pollution caused by the dust generated during the marble crushing and mining can pose serious problems to overall physiology of plants by entering through leaves. Continuous exposure of trees to dust can lead to accumulation and integration of pollutants, thereby causing foliar injuries, stomata damage, premature senescence, chlorosis, yield reduction, change in photosynthesis and transpiration making them more sensitive.(Soni et al., 2017).

Various tree species have been studied in their response to suspended particulate matter. Sett, (2017) describes the way the dust particles affect the plants and trees, and the response of the plants to the particulate-exposure. Impact of ambient air quality on micromorphological structure of leaves of the road side plant species, Ficusbenjamina has been reported by Shrivastava, (2017), while morphological and biochemical changes in Azadirachtaindica from coal combustion fly ash have been highlighted by Qadir, Sami Ullah et al. (2016).Chaudhary and Rathore, (2018) have reported the impact on castor (Ricinus communisL.) cultivars. The objective of the present study was to observe the changes caused by Marble slurry in stomatal index of three dominant tree species viz. A. lebbeck, A. indica, C. lanceolatus at the marble slurry dump yard in Kishangarh, Ajmer.

\section{MATERIALS AND METHODS}

Study area: Kishangarh is situated on the National Highway No. 8 about 30 K.M. on the North-East of Ajmer, Rajasthan.The area of the Tehsil falls between $26^{\circ} 15^{\prime}$ to $27^{\circ} 0$ ' North latitudes and $74^{\circ}$ $30^{\prime}$ to $75^{\circ} 15^{\prime}$ East longitudes. Kishangarh is the main area of marble industries (Dhanwar, 2012). It is the main market, particularly for the stone obtained from Makrana and Rajsam and region. Kishangarh is having about 523 marble gangsaws and 28 granite cutters in operation. Approximately slurry generation is $5500-6000 \mathrm{MT}$ per day. The generated slurry is being transported through tankers (capacity around 4000 litres) to the disposal site notified by Rajasthan State Industrial Development and Investment Corporation Ltd. (State Industrial Infrastructure Development Agency i.e. RIICO for Rajasthan). (Central Pollution Control Board, Bhopal, 2011-12).A dumping yard (Phase-I) has been developed in year 2005-06 of about 322 bigha area of 30-35 feets depth. This yard was designed to fulfill the 05 years of dumping requirement. Another site near to this yard has already been developed dumping yard phase-II in 532 bigha area to switch the dumping at this site. Green belt has been developed on the embankment of the dump-yards.

The route leading to this dump yard has also been lined with tree species particularly A.indica and various members of family Fabaceae. The ground flora on the route is negligible. The vegetation here is exposed to fine marble dust suspended in the environment.

The plants grown are continuously exposed to the Marble slurry pollution in atmosphere.

Collection of leaves: Leaves of $A$. indica, $A$. lebbeck and $C$. lanceolatus were collected from the vicinity of marble slurry dump yard and control samples of leaves were collected from the Botanical Garden of Samrat Prithviraj Chouhan, Government College Ajmer, which is nearly $27 \mathrm{~km}$ from the marble-slurry dumpyard.

Methodology: The leaf samples collected from control and polluted sites were thoroughly washed with tap water followed by distilled water and fixed in F.A.A. $(5 \mathrm{ml}$ formalin $+5 \mathrm{ml}$ acetic acid $+90 \mathrm{ml}$ $70 \%$ ethyl alcohol). Leaves of each species were washed carefully with water and boiled in conc. nitric acid $\left(\mathrm{HNO}_{3}\right)$ solution for 2-3min. Boiled leaves were washed thoroughly with water in watch glass and abaxial epidermis was peeled. The peels were stained with safranin and mounted in glycerine on slides. Number of stomata and epidermal cells were noted using a light microscope under $(15 \times 40)$ magnification. The stomatal index [calculated by formula given by Salisbury 
(1927)] has been considered in the present paper. $\{$ Stomatal index $=(\mathrm{S} / \mathrm{E}+\mathrm{S}) 100 \quad \ldots .$. Eq. 1 Where, $S=$ number of stomata per unit microscopic area, E = number of epidermal cells per same unit microscopic area.\}
RESULTS AND DISCUSSION

Study area: At the marble-city, Kishangarh, Ajmer, the slurry is transported to the dump-yard on whose embankment, plantation has been done.

Table 1. Stomatal index of the abaxial surface of $A$. lebbeck from the control and polluted slurry dumpyard sites of Kishangarh area.

\begin{tabular}{lllllll}
\hline Month & \multicolumn{3}{c}{ Control Area } & \multicolumn{3}{c}{ Polluted Area } \\
\cline { 2 - 7 } & No. of Stomata & No. of Epidermal cells & S.I. & $\begin{array}{l}\text { No. } \\
\text { Stomata }\end{array}$ & $\begin{array}{l}\text { No. of Epidermal } \\
\text { cells }\end{array}$ & S.I. \\
\hline Apr-14 & 19.6 & 48.25 & 28.89 & 19.14 & 52.8 & 26.61 \\
May-14 & 24.25 & 83.35 & 22.54 & 21.6 & 76.33 & 22.06 \\
June-14 & 24.5 & 100.33 & 19.63 & 17.5 & 73.5 & 19.23 \\
July-14 & 26 & 76.2 & 25.44 & 21 & 84.5 & 19.91 \\
Aug-14 & 19 & 85.67 & 18.15 & 19.4 & 66.4 & 22.61 \\
Sep-14 & 21.66 & 95 & 18.57 & 22 & 71.5 & 23.53 \\
Oct-14 & 19.4 & 87.4 & 18.16 & 21.2 & 85.6 & 19.85 \\
Nov-14 & 22 & 87 & 20.13 & 20 & 92.8 & 17.73 \\
Dec-14 & 20.5 & 101.5 & 16.8 & 22.33 & 80.33 & 21.75 \\
Jan-15 & 24.5 & 107.5 & 18.56 & 30 & 85 & 26.09 \\
Feb-15 & 25 & 108 & 18.8 & 23.5 & 92 & 20.35 \\
March-15 & 26.4 & 78 & 25.29 & 25.25 & 97 & 20.65 \\
\hline
\end{tabular}

S.I.: Stomatal index

Table 2. Stomatal index of the abaxial surface of A.indica from the control and polluted slurry dumpyard sites of Kishangarh area.

\begin{tabular}{lllllll}
\hline Month & \multicolumn{3}{c}{ Control Area } & \multicolumn{3}{c}{ Polluted Area } \\
\cline { 2 - 7 } & No. of Stomata & $\begin{array}{l}\text { No.of } \\
\text { cells }\end{array}$ & Epidermal & S.I. & No. of Stomata & $\begin{array}{l}\text { No.of } \\
\text { cells }\end{array}$ \\
\hline Apr-14 & 16.8 & 291.11 & 5.46 & 21 & 322.22 & 6.12 \\
May-14 & 19.33 & 303.7 & 5.99 & 17.6 & 328 & 5.09 \\
June-14 & 17 & 279.11 & 5.74 & 20.33 & 318.52 & 6.00 \\
July-14 & 13.6 & 287.11 & 4.52 & 24 & 322.22 & 6.93 \\
Aug-14 & 14 & 336.89 & 3.99 & 18.4 & 309.78 & 5.61 \\
Sep-14 & 13.4 & 280 & 4.67 & 15.2 & 261.33 & 5.5 \\
Oct-14 & 15.2 & 346.67 & 4.2 & 20.2 & 277.78 & 6.78 \\
Nov-14 & 20.75 & 337.78 & 5.79 & 13.4 & 284.89 & 4.5 \\
Dec-14 & 17 & 302.22 & 5.33 & 16 & 392.89 & 3.91 \\
Jan-15 & 22 & 333.33 & 6.19 & 17.2 & 352 & 4.66 \\
Feb-15 & 14.8 & 292 & 4.82 & 18.5 & 333.33 & 5.26 \\
March-15 & 17.4 & 337.33 & 4.91 & 20.5 & 350 & 5.53 \\
\hline
\end{tabular}

S.I.: Stomatal index

Table 3. Stomatal index of the abaxial surface of $C$. lanceolatus from the control and polluted slurry dumpyard sites of Kishangarh area.

\begin{tabular}{lllllll}
\hline Month & \multicolumn{3}{c}{ Control Area } & \multicolumn{2}{c}{ Polluted Area } \\
\cline { 2 - 7 } & No. of Stomata & $\begin{array}{l}\text { No.of Epider- } \\
\text { mal cells }\end{array}$ & S.I. & No. of Stomata & $\begin{array}{l}\text { No.of Epider- } \\
\text { mal cells }\end{array}$ & S.I. \\
\hline Apr-14 & 12 & 152.33 & 7.3 & 10 & 166.67 & 5.66 \\
May-14 & 13.67 & 156.67 & 8.02 & 13.67 & 165 & 7.65 \\
June-14 & 9.67 & 110 & 8.08 & 15.67 & 137.33 & 10.24 \\
July-14 & 13.33 & 128.67 & 9.39 & 18 & 125 & 12.59 \\
Aug-14 & 13 & 145.67 & 8.19 & 10 & 123.33 & 7.5 \\
Sep-14 & 21.64 & 145 & 12.98 & 10.33 & 130.67 & 7.33 \\
Oct-14 & 12.67 & 173 & 6.82 & 10 & 154.25 & 6.09 \\
Nov-14 & 13 & 157 & 7.65 & 10 & 135 & 6.9 \\
Dec-14 & 13 & 179 & 6.77 & 8.33 & 149 & 5.3 \\
Jan-15 & 11.8 & 132.8 & 8.16 & 12 & 114 & 9.52 \\
Feb-15 & 12 & 131.5 & 8.36 & 11.5 & 116.75 & 8.97 \\
March-15 & 12 & 142.75 & 7.75 & 13.5 & 155.75 & 7.98 \\
\hline
\end{tabular}

S.I.: Stomatal index 


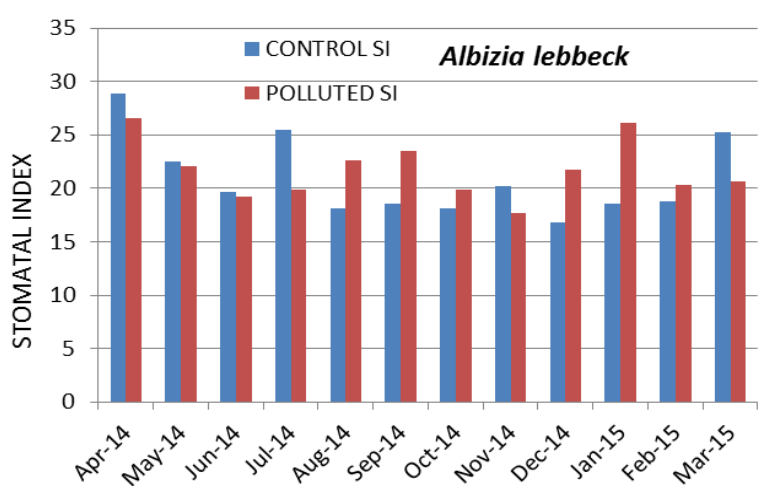

Fig.1. Stomatal index of $A$.lebbeck during the study period.

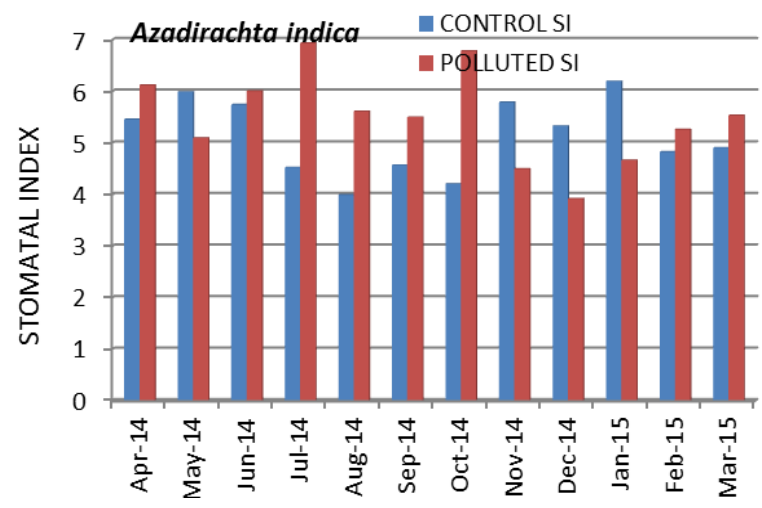

Fig. 2. Stomatal index of A.indica during the study period.

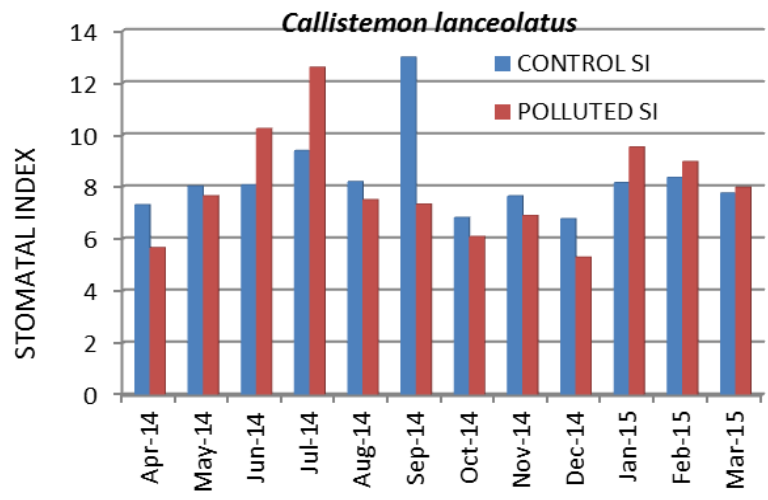

Fig. 3. Stomatal index of $C$. lanceolatus during the study period.

The vegetation of the green belt developed on the embankments is exposed to the fine dust of marble which deposits on the leaves. The suspended particulate matter is trapped by the phyllo-plane, which in turn alters the stomatal characteristics, including the stomatal index. Dust emission occurs from various primary, secondary and tertiary processes and transportation during mining and processing operations. It has been established that aerial parts of a plant especially leaves act as persistent absorbers in a polluted environment (Samal and Santra, 2002).

Plants are the natural air purifiers. They are directly affected by the suspended particulate matter present in their environment. Trees are planted for mitigating the air pollution by filtering, intercepting and absorbing pollutants in a sustainable manner Pollution stress altered the stomatal characteristics of the three investigated species, viz. A. indica, A. lebbeck and C. lanceolatus. Nevertheless, all these species are quite resistant to air pollutant actions as is obvious from the seasonal variations in the stomatal index, observed during the study period. Despite the observed modifications they continue to grow and reach sexual maturity, though the flowering was reduced considerably.

As is obvious from the tables, quantitative analysis of stomata parameters showed that leaves from the polluted site had higher number of stomata per unit area than those from control site. Similar results were reported by Ogbonna et al. (2018) for broad leaved trees and fruit trees (Ogbonna et al., 2017).

Shrivastava and Mishra (2018) reported higher values of stomatal index on both dorsal and ventral surface at polluted sites as compared to control sites. On the contrary, Pawar (2016) recorded decline in stomatal Index in stressed area leaf samples on both the surfaces. Air pollution is known to affect the stomatal index and it has been reported to decrease in some plants viz. the shrub species (Tiwari, 2012); Santalum album L. and Ficus religiosa L.(Pavana et al., 2014), Tabernaemontana divaricata L. (Gentianales: Apocynaceae) and Hamelia patens Jacq. (Gentianales: Rubiaceae)(Amulya et al., 2015) and MuntingiacalaburaL. and Ixora coccinia L (Thara et al., 2015).

Stomatal index recorded an increase in the lower epidermis of $A$. aindica and $A$. lebbeck leaves from polluted sites as compared to that with those of unpolluted site during the months of May to October. The climatic conditions of the region during these months are generally either windy or when there are monsoon showers the marble slurry is washed off the surface of the leaves. However during winter months when the slurry deposition on the leaves in particular, increases, the value of stomatal index of these leaves exhibited a decrease.

Stomatal index has been proven to be an indicator of environmental stress (Gostin, 2009). Decreased rate of photosynthesis and alteration of stomatal conductance are responsible for reduction of the stomatal index as well as dry matter content of leaf (Khan et al., 2015)

The modification of the frequency and subsequently the stomatal index in response to the environmental stress is an important means of controlling the absorption of pollutants by plants. These alterations may also be attributed to the deposition of particulate matter on the phyllo-plane in case of the present study. The use of epidermal traits of plants as indicators of environmental pollution has been emphasized. 
In case of the rough, leathery leaves of $C$. lanceolatus, stomatal index in leaves from polluted site was more during the winter months, probably because the leaf anatomy of this tree species and its canopy architecture which reduces the accumulation of the slurry dust on the phylloplane.During the windy summer months the particulate matter remain trapped on the leaf surface and influences the characteristics of the leaf stomata. According to Sharma and Butler (1973) high pubescence would reduce the amount of solar radiation incident upon the leaf surface. This alteration in the energy of leaf decreases its temperature and may alter the response to the accumulated particulate matter. Verma et al.(2006) find a significant decrease of stomatal density and stomatal index in Ipomea pes-tigridis grown under various degrees of environmental stresses (coal-smoke pollutants). This could be adaptive. The effect of pollution on stomatal frequency is species specific.

\section{Conclusion}

Of the three species under consideration, the value of stomatal index was observed to be highest for A. lebbeck , 22.06 during May and 26.08 during January followed by that for $C$. lanceolatus (7.6 and 9.5 respectively during May and January); the least being for A.indica (5.09 and 4.63 respectively during May and January). Higher values of stomatal index in the leaves of trees of $A$. lebbecka growing on the marble-slurry dumpyard particularly during winter and summer months, as compared to C.lanceolatus and A.indica, clearly indicated that it is better adapted to the prevailing abiotic stress and may be used in the green belt plantation of other marble-slurry dumpyards also.

\section{ACKNOWLEDGEMENTS}

This research was supported by University Grant Commission (UGC) - Rajiv Gandhi National Fellowship for SC Candidates, New Delhi. We are thankful to the College administration and the Department of Botany Samrat Prithviraj Chouhan Government College, Ajmer, for providing the desired support and basic infrastructure facilities that greatly assisted the present endeavour.

\section{REFERENCES}

1. Amulya, L., Kumar, N. K,. Hemanth and Jagannath, Shobha (2015).Air pollution impact on micromorphological and biochemical response of TabernaemontanadivaricataL. (Gentianales: Apocynaceae) and Hamelia patens Jacq. (Gentianales: Rubiaceae).Brazilian Journal of Biological Sciences, 2 (4):287-294.

2. Rathore, D. and Chaudhary, I. J. (2018). Ozone risk assessment of castor (Ricinus communis L.) cultivars using open top chamber and ethylenediurea (EDU). Environmental Pollution. 244.

3. CPCB - Central Pollution Control Board (2011-2012)
Bhopal A Report on the Disposal Options of Marble Slurry in Rajasthan. Zonal Office Bhopal.

4. Dhanwar, S. (2012). Study of soil affected by the waste product of marble industries. In-ternational Journal of Geology, Earth and Environmental Sciences, 2(2):16-17. ISSN: 2277-2081.

5. Fennelly, P. (1975). "Primary and secondary particulates as pollutants". "Primary and secondary particulates as pollutants . Journal Air pollut. Contr. Assoc. , 25, 697-704.

6. Gostin, Irina Neta (2009). Air Pollution Effects on the Leaf Structure of some Fabaceae Species. Not. Bot. Hort. Agrobot. Cluj 37 (2): 57-63.

7. Khan Z.S., Wolfram S., Yang P., Xiaoning Z., Hussein O., Xiongkui, H. and Muller, J. (2015). Effect of Dust Deposition on Stomatal Conductance and Leaf Temperature of Cotton in Northwest China. Water, 7 : 116-131.

8. Kushwah, R.P.S. (2014). Scientific Disposal system of Marble Slurry for Clean and Green Environment. International Journal of Engineering Sciences and Research Technology, 3(10):500-503.

9. Kushwah ,R P Singh and Chaurasiya, Dr.PBL (2015). White Washing With Marble Slurry. International Journal of Environment, Science and Technology, 1 (2): 22-25.

10.MSME (2017). Status Report on com-mercial utilization of marble slurry in Rajasthan. Ministry of Micro, Small and Medium Enterprises (MSME). Development Institute Govt. of India, 22Godown Industrial Estate Jaipur - 302006 (Raj.)

11.Ogbonna C. E., Nwafor F. I. ,Ugbogu E. A., Nwazue, K.(2018). Assessment of Foliar Parameters and Air Pollution Tolerance of Broad Leaved Trees in Ugwuele Quarry Site, Uturu, Nigeria.Applied Ecology and Environmental Sciences, 6(2 ): 48-56.

12.Ogbonna, C. E., Ugbogu, A. E., Otuu, F.C., Mbaogu, N. E. and Johnson, A.R. (2017).Influence of rock quarrying activities on the physiochemical characteristics of selected edible fruit trees in Uturu, Abia State, Nigeria. Applied Ecology and Environmental Sciences, 5 (1): 1-9, 2017

13.Pavana, H.C., Hemanth kumar, N.K., Veena, M. and Jagannath, S. (2014). Air pollution induced changes on micromorphological and biochemical parameters of two plant species: Santalum album L. and Ficusreligiosa L. International Journal of Pharmaceutical Research and Development,6(9): 8-12.

14.Pawar, Anita, (2016). Impact of urban air pollution on epidermal traits of Amaranthus viridis growing along the road side. Journal of Pure and Applied Science and Technology, 6 (1) :7-10.

15.Qadir, S. U. , WAS, Vaseem Raja (2016). Morphological and biochemical changes in Azadirachta indica from coal combustion fly ash dumping site from a thermal power plant in Delhi, India. Ecotoxicology and Environmental safety 129:320-328

16.Rai, P. K. and Panda, L. L. S. (2014). Leaf dust deposition and its impact on biochemical aspect of some roadside plants of Aizawl, Mizoram. International Research Journal of Environment Science,3(11):1419

17.Salisbury, E.J. (1927). On the causes and ecological significance of stomatal frequency with special referencesto woodland flora. Phil. Trans. R. Sco. B.,216:1 $-65$

18.Samal, A.K. and Santra, S.C.(2002). Air quality of 
Gahlot, L. and Khanna, V. / J. Appl. \& Nat. Sci. 11(1): 193-198 (2019)

Kalyani Township (Nadia, West Bengal) and its impact on surrounding vegetation. Ind. J. Environ. Health,(44):71-76.

19.Saxena, N., Yadav, R.K. and Arif, M. (2017). Study of Plant Growth and soil pollution by Marble Slurry. $E Q A, 26: 41-46$.

20.Sett, R. (2017) Responses in Plants Exposed to Dust Pollution. Horticult. International Journal, 1(2): 00010. DOI: 10.15406/hij.2017.01.00010

21.Sharma, G.K. and Butler, J.(1973).Leaf cuticular variations in TrifoliumrepensL.As indicators of environment pollution.Jr. of Environ. Poll.5: 267 - 293.

22.Shrivastava, Riya (2017). Studies on ambient air quality and its impact on micromorphological structure of leaves of the road side plant species, Ficusbenjamina in Rewa city (M.P.), India. International Journal of Current Research, 9(5): 50147-50152

23.Shrivastava,Riya and Mishra, Arpana (2018). Air pollution induced changes in foliar micro-morphology of road side species Thevetiaperuviana and Plumeria alba in Rewa City, MP, India . International Research Journal of Environmental Sciences, 7(3):1-7.
24.Soni ,Anuj, Aseri, G. K. and Jain, Neelam (2017).Impact of Air Pollution caused by Mining and Marble Dust on Foliar Sensitivity through Biochemical Changes. International Journal of Engineering Research and Technology. Special Issue, ICBA - 2016 Conference Proceedings.

25.Supe,G. N. And Gawande, S. M.(2015).Effects Of Dustfall On Vegetation. International Journal of Science and Research, 4 (7): 2184-2189.

26. Thara SB, Hemanth kumar NK and Jagannath $S$ (2015) Micro-morphological and biochemical response of Muntingia calabura L. and Ixora coccinia L. to air pollution. Research in Plant Biology 5(4):11-17

27.Tiwari, S. (2012). Air Pollution Induced changes in Foliar Morphology of two shrub species at Indore city, India Research Journal of Recent Sciences, 2(ISC2012), 195-199.

28.Verma, R. B., Mahmooduzzafar, T. O. Siddiqi and M. Iqbal (2006). Foliar Response of Ipomea pes-tigridis L. to coal smoke pollution, Turkish Journal of Botany. 30(5):413- 417. 